Article

\title{
Identifying the Socio-Spatial Logics of Foreclosed Housing Accumulated by Large Private Landlords in Post-Crisis Catalan Cities
}

\author{
Aaron Gutiérrez * (D) and Antoni Domènech (D) \\ Department of Geography, Universitat Rovira i Virgili, 43480 Vila-seca, Spain; antoni.domenech@urv.cat \\ * Correspondence: aaron.gutierrez@urv.cat
}

Received: 6 April 2020; Accepted: 4 May 2020; Published: 8 May 2020

\begin{abstract}
The article analyses the socio-spatial logic behind the accumulation of foreclosed housing in the hands of large private landlords in the neighbourhoods of all the Catalan cities with over 100,000 inhabitants. Spatial regression and clustering techniques are applied to identify the determinants of the concentration patterns of 10,725 housing units in these cities. The socioeconomic variables, such as income level, percentage of foreign population, level of studies or percentage of unemployed residents, are identified as key explanatory factors of clustering of foreclosures in working-class neighbourhoods. A high presence of previously mortgaged homes is a variable especially relevant in the case of working-class neighbourhoods, but it has no incidence in the case of the medium-high class neighbourhoods. Our findings provide a detailed urban geography of the housing accumulated by banks which, at the same time, correspond to areas in which the vulture funds are focusing their business in the present and in the forthcoming years. New evidences of the spatial logic of the housing crisis and detailed information for the understanding of the new scenarios that have emerged during the post-crisis phase are revealed.
\end{abstract}

Keywords: spatial analysis; foreclosures; evictions; housing crisis; Moran's I; spatial error model; K-means clustering

\section{Introduction}

Throughout the 1990s and a large part of the first decade of the 21st century, Spain experienced a clear intensification in the tendency for extensive and expansive urbanisation. In the worst years of the property bubble (1997-2007), it maintained an unprecedented rhythm of new-housing construction [1-3]. In fact, it registered the highest rate of new housing construction in Europe. Within a context in which the mortgage had become consolidated as the main formula for obtaining access to housing, the indebtedness of families grew exponentially $[4,5]$. The hypertrophy of housing production experienced during this period, which was fed by the housing-price bubble and by government policies effectively promoting it, therefore culminated in a historic expansion in mortgage credit and family indebtedness [6,7]. The decade following the global financial crisis has been characterised by a fall in housing prices, the mortgage crisis, and the proliferation of evictions. These processes have been accompanied and fuelled by policies of austerity and the rescue of the banking system. In short, during this period the Spanish property market has passed through a complete "boom and bust" cycle, typical of the urbanisation of capital $[4,8]$.

Since the bursting of the property bubble, the most predatory consequences of the Spanish financial and property model have been clearly evident. These have been based on the conceptualisation of housing as a product for investment and speculation $[9,10]$. According to data from the Spanish General Council of the Judiciary, during the period 2008-2016, in the whole of Spain there were more 
than 695,000 mortgage foreclosures of all types of property (including plots, buildings, premises, and housing) that did not only correspond to the purchase of first residences for families. Among that total, 137,000 took place in Catalonia. Finally, that foreclosures resulted in more than 327,000 evictions for the whole Spain (n.d. for Catalonia).

The so-called "solution" to the Spanish property and financial crisis has centred around mortgage foreclosures and the transfer of public funds to the financial sector via bank rescues. In fact, it has been the same banks that were rescued using public money that have accumulated most empty housing as a result of mortgage foreclosures. The data available for Catalonia show that the rescued banks have accumulated around $65 \%$ of the empty housing resulting from mortgage foreclosures [11,12].

As a consequence, banks have become the main housing landlords in Spain. This has given them an important strategic position in the management of the next expansionist phase of the housing cycle. This accumulation of housing by banks has been accompanied, and indeed encouraged, by what have been referred to as processes of restructuring and sanitising the Spanish financial sector. This restructuring process has implied rescuing the banks with public money and the "bankarisation", or conversion, of regional savings banks (restructuring). This sanitising process has also implied the transfer of assets (land, empty housing promotions and housing acquired through mortgage foreclosures) from the banks to the SAREB (the Spanish acronym for the "Sociedad de Gestion de Activos Procedentes de la Reestructuración Bancaria"-Company for the Management of Assets proceeding from the Restructuring of the Banking System) [13-15].

In recent years, banks and the SAREB have been selling parts of their property portfolios to international equity funds. This process has been accelerated and fuelled by laws that have given very favourable fiscal conditions to SOCIMIs (the Spanish REITs-investment companies that manage housing rentals, which are popularly known as vulture funds). In this way, Law 16/2012 modified and improved what were already very favourable conditions for these companies with respect to Law $11 / 2009$, particularly as it reduced corporation tax. Various studies have highlighted the emergence of investment funds in Spain and the key role that they would subsequently play in the housing market $[8,14,16]$. They essentially arrived in Spain acquiring these housing portfolios from banks that had been saved with public funds [4]. Within this context, Blackstone has already become the largest housing landlord in Spain [17-19]. The great difference between the current situation and that during the property bubble (1997-2007) is therefore that there are now new key actors in the market: the vulture funds.

The evidence points to the ongoing expansionist phase not focusing on mortgage credit, but rather on profits obtained from a rental market with rising prices $[20,21]$. This process would not have been possible without the wave of evictions and mortgage foreclosures that has permitted the accumulation of housing, first in the hands of the banking sector, and now in those of SOCIMIs, which will play a key role in the next property cycle $[14,20,21]$.

Starting from this context, the main objective of this work is to analyse the socio-spatial logic behind the accumulation of housing in the hands of large private landlords in Catalan cities. This will firstly make it possible to characterise the neighbourhoods that have been the main scenes of the mortgage crisis. Secondly, this will allow us to identify where the housing stock that will be managed by the major vulture funds in the coming years is located. In short, we aim to identify and characterise which urban areas constitute the central spaces where the two sides of this same coin have taken place. On the one hand, these have been spaces with concentrations of mortgage foreclosures and evictions and, on the other, they are the areas in which the vulture funds will focus their business in the coming years, profiting from housing thanks to the stock accumulated there. We also aim to determine the socio-economic variables that determine the spatial logics of that phenomenon.

This study is based on an extraction of data from the register of empty housing units owned by large private landlords belonging to the Catalan Housing Agency, which is a public entity belonging to the Government of Catalonia. At the moment of the extraction (March 2016), the vast majority of these landlords are Spanish banks and related real estate companies. This database contains both 
empty housing, resulting from mortgage foreclosures and the eviction of residents, and new housing that has not previously been occupied. In this study, we focused on housing acquired via mortgage foreclosure and eviction of former residents. This dataset contains individual information for each housing unit and all of them are geolocated by postal address. This provides a wide sample of all the evictions associated with mortgage foreclosure that took place in Catalonia. Previous studies estimate that this is a sample covering more than $40 \%$ of the total number of cases (registered in the period 2008-2015) [12,22]. At the same time, they offer an exact register of all the housing stock accumulated by the banking sector at March 2016.

In this study we analyse the socio-spatial logic of the housing accumulated by banks in all the cities in Catalonia with over 100,000 inhabitants using geolocated individual data for each housing unit ( $\mathrm{n}=10,725$, for nine cities). These data had not previously been exploited at the submunicipal scale except in Barcelona [22] which, for this reason, has been excluded from this study. This study therefore provides a detailed geography of the housing accumulated by banks in Catalan cities during the central years of the mortgage crisis. Our study contributes to the field by adding new evidences of the spatial logic of the housing crisis and providing detailed information for the understanding of the new scenarios that have emerged during the post-crisis phase.

There is a growing literature that analyses the spatial logic of evictions and mortgage foreclosures in cities throughout the world and the emergence of new large private landlords in post-crisis scenarios. The USA is the country with the highest literature in the field. In addition of studies on the spatial clustering of foreclosures, other have analysed their contribution to: multiple deprivation [23], deterioration of public health [24], forced displacements [25], racial segregation [26], increases in crime rates [27], and the falling of housing market values [28,29], among others. There is also a growing literature on the spatial logics of foreclosures and evictions in Spain (e.g., [12,22,30-33]). There are various studies based in cities in Ireland [34], Greece [13], among others. The sources of data used have been many and varied, but most of them have not individual and geolocated data for each housing unit. There are studies based on primary and official sources and others based on multiple secondary and alternative sources. Even so, to date there has been no publication that has systematically analysed all of the cities in a particular region or state using the same source and approach. Herein lies one of the central points of our contribution to the literature in this field. The empirical evidence that is provided by the article is not based on a single case study (one city), but rather on all the cities with over 100,000 inhabitants in Catalonia.

The rest of the article is organised as follows: After this introduction, the second section presents the data used and the methods applied. The third section presents the results achieved. In the fourth and final section there is a discussion of the implications of our findings and the main conclusions that can be drawn from this study.

\section{Materials and Methods}

In Spain there is no official source of open-access information that allows an inframunicipal scale analysis of foreclosures and evictions. For this reason, some studies on the geography of foreclosures and evictions in Spain use the available open-access data aggregated at judicial district level [30,31]. Other researchers working in this field have used alternative data sources to overcome the limitations of the open-access official data. They have done this by using such techniques as scraping advertisements published on the housing websites of real estate companies linked to main Spanish banks $[11,15,32,35]$ and directly extracting data manually from primary sources in each specific judicial district site $[33,36,37]$.

The present study used data from the register of empty housing units owned by large private landlords which was created by the Catalan Housing Agency in March 2016. Its creation formed part of the implementation of Law 14/2015 in Catalonia, relating to the taxing of empty housing units accumulated by banks via foreclosures. Banks entities were required to provide the Catalan Housing 
Agency with accurate data on any empty housing units in their possession. From these data, the agency then produced an exhaustive registry which was to serve as a basic reference for tax collection.

The registry records the full postal address of each housing unit and its owner. Information about all the housing units located in Catalan municipalities with more than 100,000 inhabitants, excluding Barcelona, was selected for the present study and geo-referenced, as shown in Figure 1. In total, banks had accumulated 10,725 housing units in the nine Catalan cities with more than 100,000 inhabitants. Each point on the maps in Figure 2 corresponds to one of these housing units. The number of housing units owned by banks (HOBs from now) in each city is as following: Badalona: 1307; Hospitalet de Llobregat: 1656; Lleida: 1209; Mataró: 537; Reus: 955; Sabadell: 1356; Santa Coloma de Gramenet: 924; Tarragona: 1069; Terrassa: 1712.

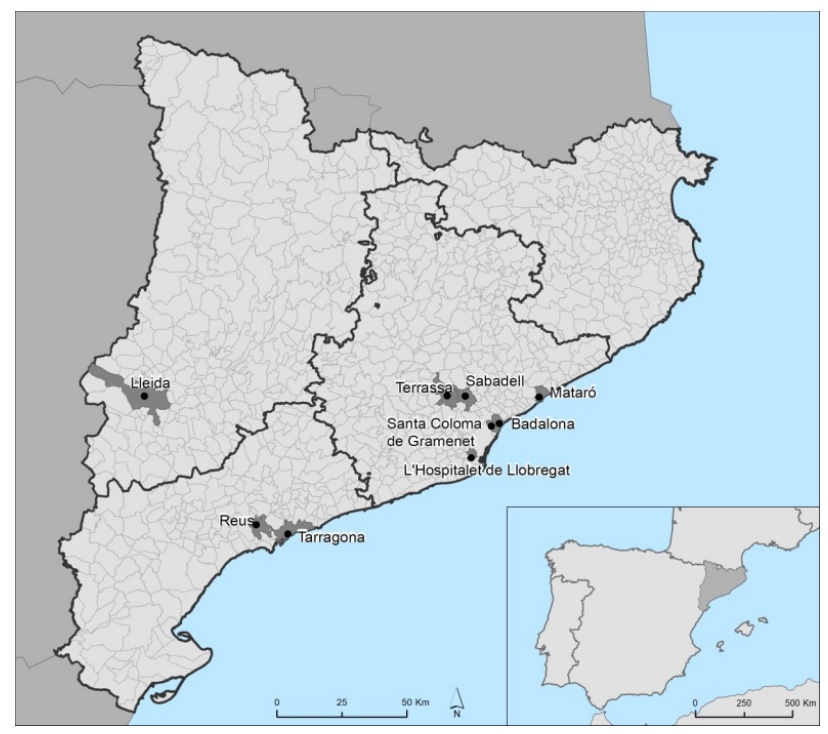

Figure 1. Nine Catalan cities studied. Source: own elaboration.

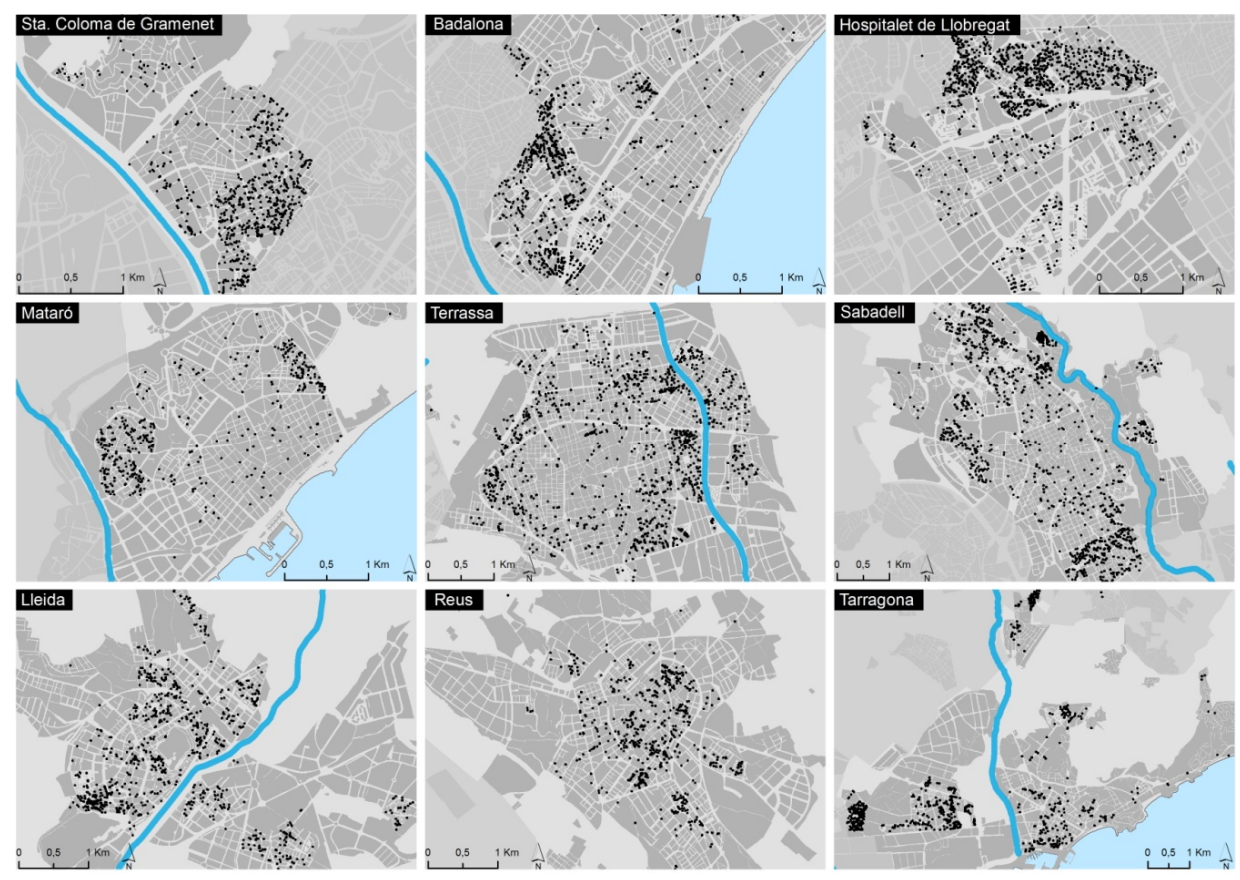

Figure 2. Geolocated housing units owned by banks (black points) in the nine cities studied. Source: own elaboration. 
Various geostatistical techniques were applied in order to meet the, previously mentioned, objectives of our research. Firstly, a local indicator of spatial association (LISA) was used to establish whether or not there was a spatial concentration of HOB in certain areas of the cities studied. More concretely, the local Moran's spatial autocorrelation indicator [38] was used through the free software GeoDa@ [39]. The final maps were subsequently generated with version 10.3 of ArcGIS from ESRIC.

The variable introduced to carry out the analysis was the number of HOB per census tract. This variable was not standardised based on the number of housing units per census tract (as it has been in other studies, such as [22,35]), since the main interest of our study was to identify the areas with the greatest accumulation of HOB.

The local Moran's I requires a weight matrix that defines a spatial relationship between each geographic unit and its neighbouring geographic units. In this study, a queen criterion was used to build the weight matrix. This assumes that spatial neighbours can be defined as all the elements that share boundaries and vertices, as opposed to the rook criterion, in which only features that share sides are considered neighbours [39], or the bishop type matrix, in which only entities that share vertices are considered neighbours [40]. The indicator could therefore be defined as follows:

$$
I_{i}=\frac{\left(\chi_{i}-\mu\right)}{m_{0}} \sum_{j=1, j \neq i}^{n} \omega_{i, j}\left(\chi_{j}-\mu\right)
$$

where $\chi_{i}$ is an attribute of feature $i, \mu$ is the mean of the corresponding attribute, $\omega_{i, j}$ is the spatial weight between feature $i$ and $j, n$ is the number of features (in this study the census tracts), and:

$$
m_{0}=\frac{\sum_{i=1, j \neq i}^{n}\left(\chi_{j}-\mu\right)^{2}}{n-1}
$$

The local Moran's indicator identified areas made up of census tracts with high values of housing units owned by financial entities (hot spots), and also areas with low values (cold spots) and statistically significant spatial outliers (at least at $p<0.05$ ). We then analysed the socioeconomic characteristics of the neighbourhoods in which $\mathrm{HOB}$ were concentrated. According to previous literature in the field, it is supposed that the concentration of $\mathrm{HOB}$ would be found in the most vulnerable areas of each city. Following this logic, statistical data from the 2011 Population Census and income-related variables from the 2015 provided by the Spanish National Institute of Statistics (INE) were collected and combined with the 1075 census tracts of the nine cities analysed, as displayed in Table 1.

\begin{tabular}{|c|c|c|}
\hline Typology & Description & Source \\
\hline Housing & Housing units owned by banks (HOB) & Catalan Housing Agency \\
\hline Origin & Percentage of foreign population (2011) & Spanish Census (2011) \\
\hline Education level & $\begin{array}{l}\text { - Percentage of population without studies: includes } \\
\text { illiterate people and people without studies (2011) } \\
\text { - } \quad \text { Percentage of population with higher education studies: } \\
\text { includes bachelor, master and doctorate degrees (2011) }\end{array}$ & Spanish Census (2011) \\
\hline Economic & $\begin{array}{ll}\text { - } & \text { Percentage of unemployed population (2011) } \\
- & \text { Percentage of employed population }(2011) \\
- & \text { Percentage of population with income per unit of } \\
\text { - } & \text { Aversumption below } 40 \% \text { of the Spanish median }(2015)^{1} \\
& \text { Averagehold income }(2015)^{1}\end{array}$ & $\begin{array}{l}\text { Spanish Census (2011) } \\
\text { INE experimental }^{2}\end{array}$ \\
\hline Financial & Percentage of mortgaged homes (2011) & Spanish Census (2011) \\
\hline
\end{tabular}

Table 1. Socioeconomic indicators used. 
Table 2 presents the results of the Pearson's correlation coefficients between the variables in Table 1. Pearson's coefficients range from +1 to -1 . Values close to zero show the absence of statistical correlation between the variables studied. The closer the result is to 1 or -1 , the stronger the positive, or negative, correlation. As can be seen, all these variables are associated with the dependent variable, but moderate correlations also appear between them.

Table 2. Pearson's correlation coefficients between variables considered.

\begin{tabular}{|c|c|c|c|c|c|c|c|c|c|}
\hline & [a] & [b] & [c] & [d] & [e] & [f] & [g] & [h] & [i] \\
\hline $\begin{array}{l}\text { [a] Housing units } \\
\text { owned by banks }\end{array}$ & 1 & & & & & & & & \\
\hline $\begin{array}{l}\text { [b] Foreign } \\
\text { population (\%) }\end{array}$ & 0.372 ** & 1 & & & & & & & \\
\hline $\begin{array}{l}\text { [c] Employed } \\
\text { population (\%) }\end{array}$ & $-0.276^{* *}$ & $-0.348^{* *}$ & 1 & & & & & & \\
\hline $\begin{array}{l}\text { [d] Unemployed } \\
\text { population (\%) }\end{array}$ & $0.316^{* *}$ & 0.349 & $-0.446^{* *}$ & 1 & & & & & \\
\hline $\begin{array}{l}\text { [e] Population (\%) } \\
\text { without studies }\end{array}$ & $0.172 * *$ & 0.083 & $-0.433^{* *}$ & $0.239^{* *}$ & 1 & & & & \\
\hline $\begin{array}{l}\text { [f] Population (\%) with } \\
\text { higher education }\end{array}$ & $-0.289 * *$ & $-0.284^{* *}$ & 0.493 ** & $-0.462 * *$ & $-0.545^{* *}$ & 1 & & & \\
\hline $\begin{array}{l}\text { [g] Population }(\%) \text { with } \\
\text { income }<40 \% \text { of the } \\
\text { national median }\end{array}$ & $0.615^{* *}$ & 0.489 ** & $-0.455^{* *}$ & $0.422 * *$ & $0.363^{* *}$ & $-0.464^{* *}$ & 1 & & \\
\hline $\begin{array}{l}\text { [h] Average household } \\
\text { income }(€)\end{array}$ & $-0.441^{* *}$ & $-0.383^{* *}$ & 0.470 ** & $-0.487^{* *}$ & $-0.522 * *$ & $0.758^{* *}$ & -0.717 & 1 & \\
\hline $\begin{array}{c}{[\mathrm{i}](\%) \text { Mortgages }} \\
\text { homes }(\%)\end{array}$ & $0.116^{* *}$ & $-0.182^{* *}$ & 0.270 ** & -0.042 & $-0.244^{* *}$ & 0.069 * & -0.155 & 0.100 ** & 1 \\
\hline
\end{tabular}

A stepwise linear regression model (ordinary least squares-OLS-method) was applied to the 1075 census tracts to prevent collinearity between explicative variables. The OLS can be defined as follows:

$$
Y=\beta_{0}+\beta_{1} x_{1}+\beta_{2} x_{2}+\ldots \beta_{n} x_{n}+\varepsilon
$$

where $Y$ is the dependent variable that we are modelling (housing units owned by banks); $\beta_{0}$ is the intersect; $\beta_{\mathrm{n}}$ are the coefficients that determine the relationship and intensity of each explanatory variable with respect to the dependent variable. The sign (+/-) associated with the coefficient indicates whether the relationship is positive or negative; and $\varepsilon$ is the residual error, that is, the portion of the dependent variable that is not explained by the model.

The definitive model selected the percentage of foreign population, the percentage of population with an income lower than $40 \%$ of the median national income, the percentage of mortgaged homes and the percentage of unemployed population as the explicative variables. The multicollinearity of the configured model was rejected as the variance inflation factor (VIF) provided values of between 1 and 2 that were far below the limit of 10 agreed by various academics $[42,43]$.

These four variables were used to carry out a stepwise linear regression to determine their role in explaining the concentration of $\mathrm{HOB}$ in each of the nine cities studied. The VIF value ranged between 1 and 2, indicating the absence of multicollinearity. After identifying the key explicative variables for each city, spatial dependence was tested following the spatial regression model selection decision rule [44]. This rule is based on the fact that certain assumptions about the random error of the regression equations need to be guaranteed in order to obtain accurate regression coefficients: (a) the random errors must have a mean value of zero; (b) the random errors must have a constant level of variance and be uncorrelated; (c) the random errors must have a normal distribution. These assumptions may, however, be violated due to the existence of spatial dependence. This means that a value observed at one location may depend on the values observed at neighbouring locations.

In our study, all the diagnostics for spatial dependence of the OLS models highlighted the presence of autocorrelated random errors. As a result, we used the Lagrange multiplier-error (LM-Error) and Lagrange multiplier-lag (LM-Lag) test statistics and their robust forms to determine the definitive model specification. When the LM-Error was significant, the OLS was discarded and the spatial error model was run. This specification modifies the OLS by considering that the error terms across different 
spatial units are correlated, as shown in the first scheme in Figure 3. On the contrary, when the LM-Lag was significant, the spatial lag model was run. In this model, the dependent variable $Y$ in a census tract $i$ is affected by the explicative variables in both census tracts $i$ and $j$, as displayed in the second scheme in Figure 3.
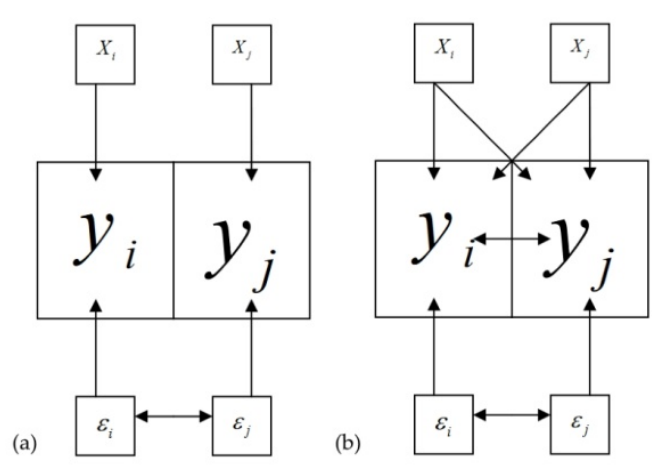

Figure 3. Spatial dependence in the spatial error models (a) and spatial lag models (b). Source: Adapted from “Spatial regression with GeoDa” (https://s4.ad.brown.edu/Resources/Tutorial/Modul2/ GeoDa3FINAL.pdf).

Finally, after performing the spatial regressions, an unsupervised clustering analysis was applied in order to socio-economically characterise the different neighbourhoods analysed. The algorithm used was a K-means clustering and all the census tracts in the nine cities analysed (1075) were included in the analysis. This method looks for a solution in which all the census tracts within each cluster are as similar as possible, and all the clusters are as different as possible [45]. Although the pseudo F-statistics recommended classifying the 1075 census tracts into two groups, we decided to use four in order to ensure the readability of the results.

\section{Results}

The geostatistical techniques applied in this study allowed us to analyse the spatial distribution patterns of HOB. We detected an important, uneven spatial distribution of these housing units at the infra-municipal scale. Overall, they tended to be concentrated in neighbourhoods with indicators of greater socioeconomic vulnerability. The application of the local Moran's autocorrelation indicator detected the degree of clustering of HOB. Table 3 shows the results for this indicator taking the census tracts and number of $\mathrm{HOB}$ as the units of analysis. The higher the autocorrelation coefficient, the less probability there was of $\mathrm{HOB}$ having a random distribution within each city. In general, the nine cities had coefficients close to, or greater than, 0.200 .

Table 3. Moran's I coefficient per city ${ }^{1}$.

\begin{tabular}{cccccc}
\hline Sta. Coloma Gramanet & 0.547 & Mataró & 0.407 & Lleida & 0.362 \\
Badalona & 0.422 & Terrassa & 0.264 & Reus & 0.202 \\
l'Hospitalet de Llobregat & 0.499 & Sabadell & 0.180 & Tarragona & 0.533 \\
\hline \multicolumn{7}{c}{ All coefficients are statistically significant at $99.9 \%}$.
\end{tabular}

Figure 4 shows mapped results for the local Moran's I. In general, the results obtained coincided with the vulnerable neighbourhoods catalogued by the Observatory of Urban Vulnerability of Spain's Ministry of Transport, Mobility and Urban Agenda [46]. This catalogue takes into account the percentages of the population that are: unemployed, of foreign origin, without studies, and housed in buildings that are in a bad or poor state of conservation. 


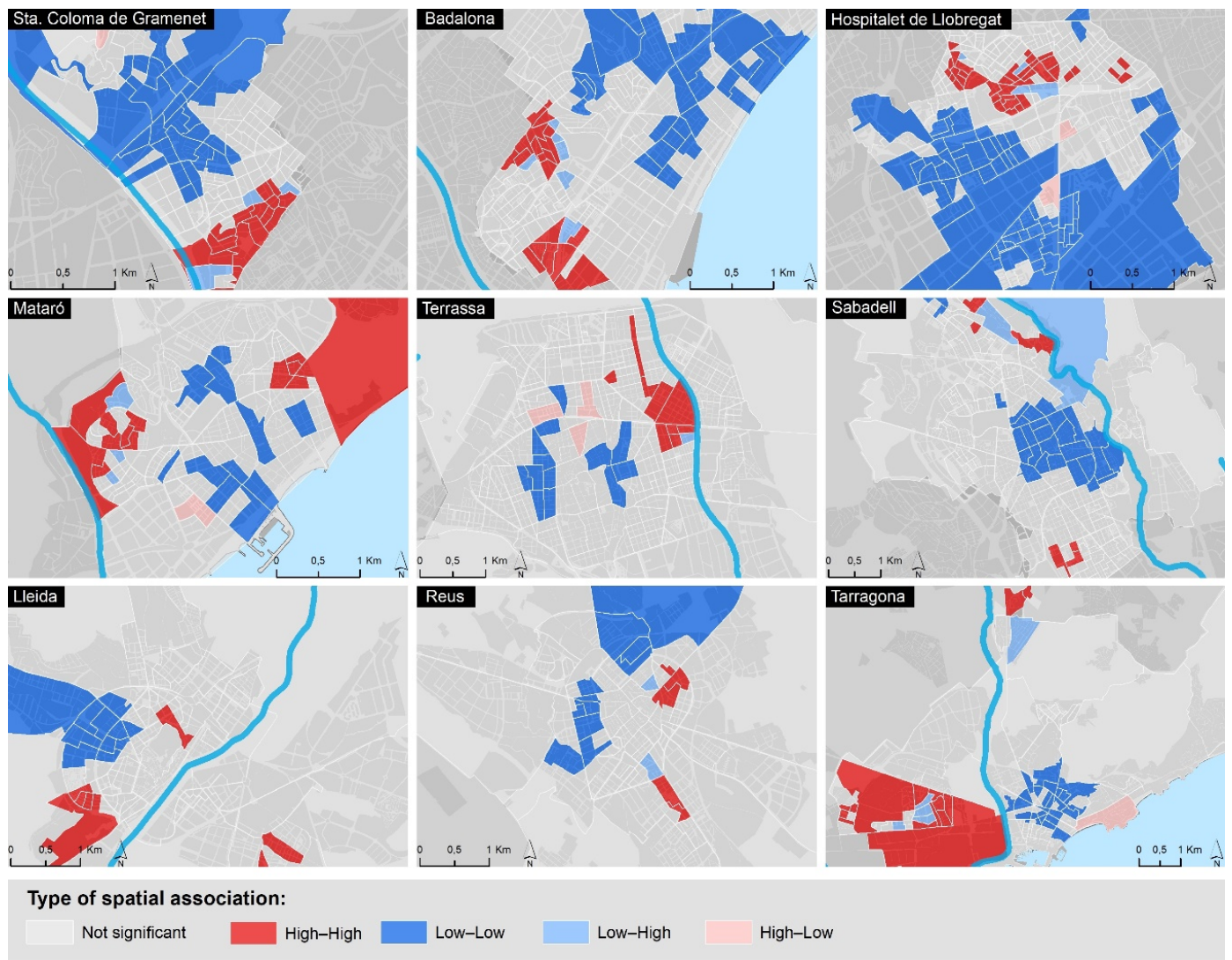

Figure 4. Results for the local Moran's indicator in the nine cities studied. Source: Own elaboration based on data from the Catalan Housing Agency.

According to the Moran's I coefficients, clustering was especially prominent in l'Hospitalet de Llobregat, Tarragona and Santa Coloma de Gramenet, with spatial autocorrelation coefficients greater or equal to 0.500 . In l'Hospitalet de Llobregat, clustering was particularly prominent in the neighbourhoods of Les Planes, Florida and Torrassa. In Tarragona, the westernmost neighbourhoods and an urbanization to the north of the city (Sant Salvador) were the areas with the greatest presence of census tracts with high-high association values. All these neighbourhoods had been composed by social housing developments during the 1960s in response of the migration flows arriving from the southern regions of Spain. In Santa Coloma de Gramenet, an important hotspot was detected in the Llefià neighbourhood, which is a transition zone between this municipality and Badalona. In fact, the results for the city of Badalona showed the presence of a spatial concentration of high values that united the two cities and also another concentration in the area bordering on the municipality of Sant Adrià de Besòs.

In Mataró, the old town presented a typology of high-high spatial association, and therefore, significant spatial clusters. In Lleida, on the other hand, the polarization between the wealthiest neighbourhoods and the most vulnerable ones was clearly evident. While the Ciutat Jardí area (in the west of the city) presented a low-low spatial association, the Mariola area (in the south of the city) had a significant high-high cluster. In Reus, Sabadell and Terrassa, the neighbourhoods with high-high values were very clearly identifiable, albeit with lower coefficients. In Reus, significant spatial concentrations were detected in the Fortuny neighbourhood, in the southeast of the city, and in the Muralla Nord area. In Terrassa, areas with clusters of high values were found in the Ca n'Anglada neighbourhood (in the east of the city, near a stream), while in Sabadell, they were found in the northern neighbourhoods of the city: Can Puiggener, La Plana del Pintor and Can Deu and in the southern neighbourhood of Espronceda-Campoamor. All of them correspond with some of the most deprived urban areas of each city. 
The regression model applied for the set of nine cities explained $40 \%$ (Adjusted $\mathrm{R}^{2}=0.428$ ) of the concentration of housing accumulated by large property holders in certain census tracts, as shown in the results presented in Table 4 . All the variables introduced into the model were statistically significant at $99.9 \%$. If there were other variables available at the inframunicipal scale, such as the total housing surface, the market price of both housing for sale and for rental, and the different land uses, the model would no doubt have improved its measures of fit [22]. Nevertheless, with the data available, the model allowed us to determine the main variables that influenced the accumulation of housing stock in certain neighbourhoods of the nine cities analysed. More concretely, these were the areas with the highest percentages of foreign population, the greatest percentages of unemployed people, the highest percentages of housing units pending payment, and, most importantly, major percentages of population with annual incomes that were below $40 \%$ of the Spanish median income. Not only was the latter the variable with the highest coefficient in the joint model, but it also appeared to be a key indicator in all the models developed for each of the cities studied, as shown in Table 4.

Table 4. Regression results.

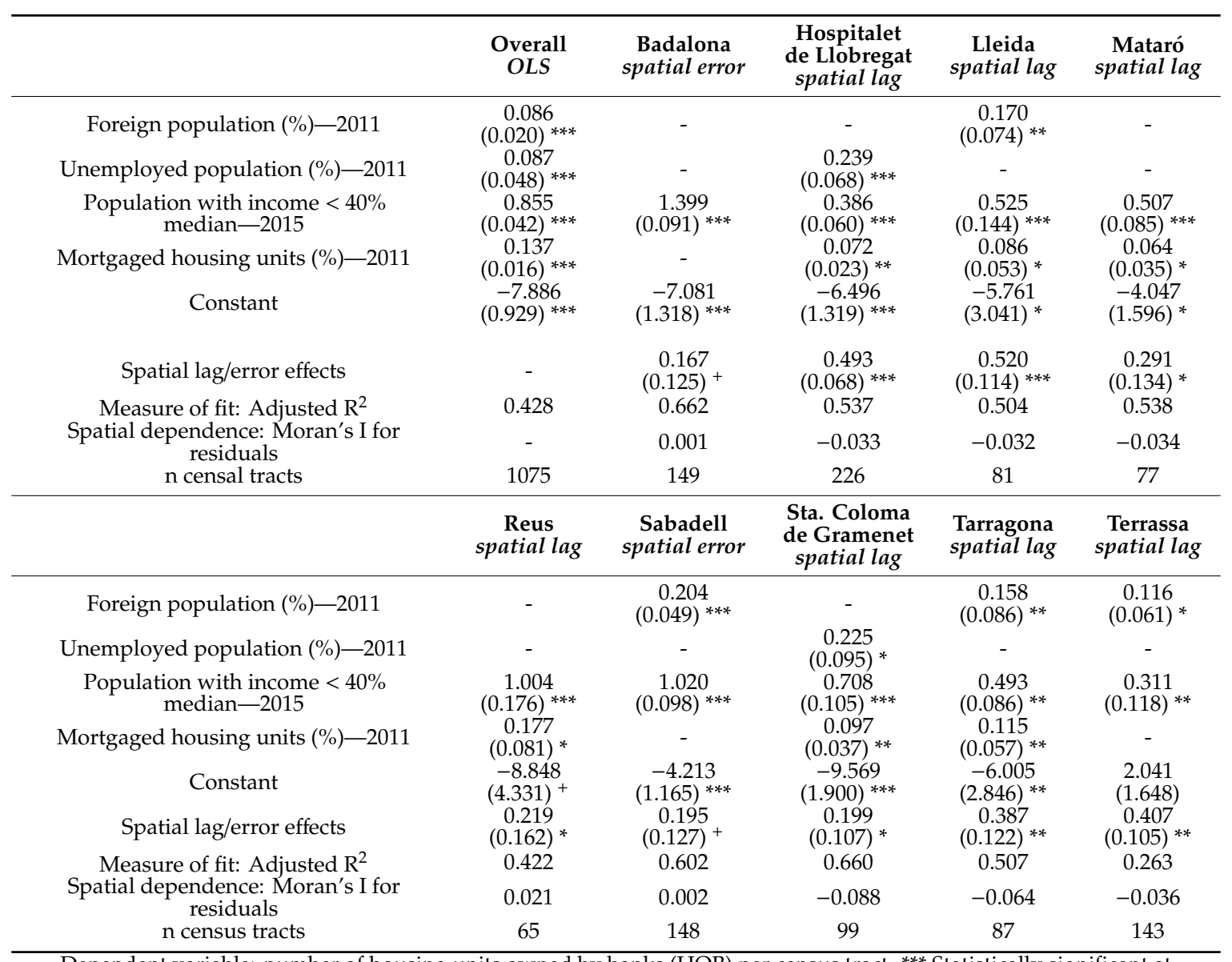

Dependent variable: number of housing units owned by banks (HOB) per census tract. ${ }^{* * *}$ Statistically significant at $99.9 \%(p<0.01) ;^{* *}$ at $95.0 \%(p<0.05) ;^{*}$ at $90.0 \%(p<0.10){ }^{+}$at $80.0 \%(p<0.20)$.

It is important to mention that none of the stepwise linear regressions carried out for each of the cities produced models with more than three explicative variables. In Badalona, for instance, only one entered into this specification. After the independent variables for each city had been detected, the spatial regression model selection decision rule [44] was followed to test whether there was any spatial dependence. In all the models, it appeared to exist and therefore spatial lag models or spatial error models were applied. (Table 4 and the methods section provide further information.)

With the exception of Terrassa and Reus, all the spatial regressions presented an adjusted $\mathrm{R}^{2}$ value that was higher than 0.500 and, therefore, greater than that of the joint model. In all of the 
models, the percentage of population whose income per unit of consumption was less than $40 \%$ of the Spanish median appeared to be the indicator with the greatest impact on the dependent variable. In fact, in Badalona, this indicator combined with the spatial error effect turned out to be the model's only explicative variable. In the spatial regression models in which the percentage of housing units pending payment turned out to be an explanatory variable, it was the one with the lowest coefficient. This shows that, despite the fact that this variable represents an indicator of family over-indebtedness, the indicators with the greatest influence on the concentration of foreclosed housing units in certain neighbourhoods were those related to social vulnerability and spatial dependence.

Finally, the results of the K-means clustering revealed four clearly differentiated groups. Between them, it was not only possible to note clear residential segregation, but also an uneven concentration of $\mathrm{HOB}$ in working-class neighbourhoods. These findings were consistent with those previously highlighted in other territorial contexts. Table 5 presents the statistics for each of the variables included in the model; they correspond to the same variables selected by the stepwise regression. Meanwhile, Figure 5 shows a graph of the standardised values.

Table 5. Overall variable statistics for each of the groups of neighbourhoods identified.

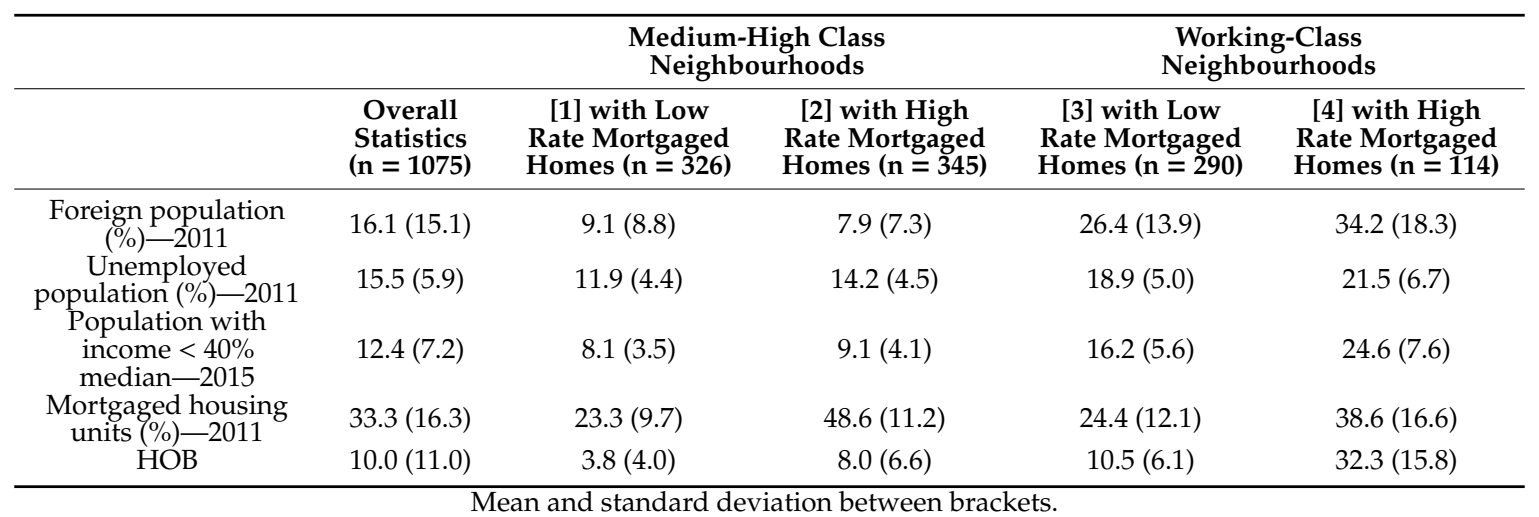

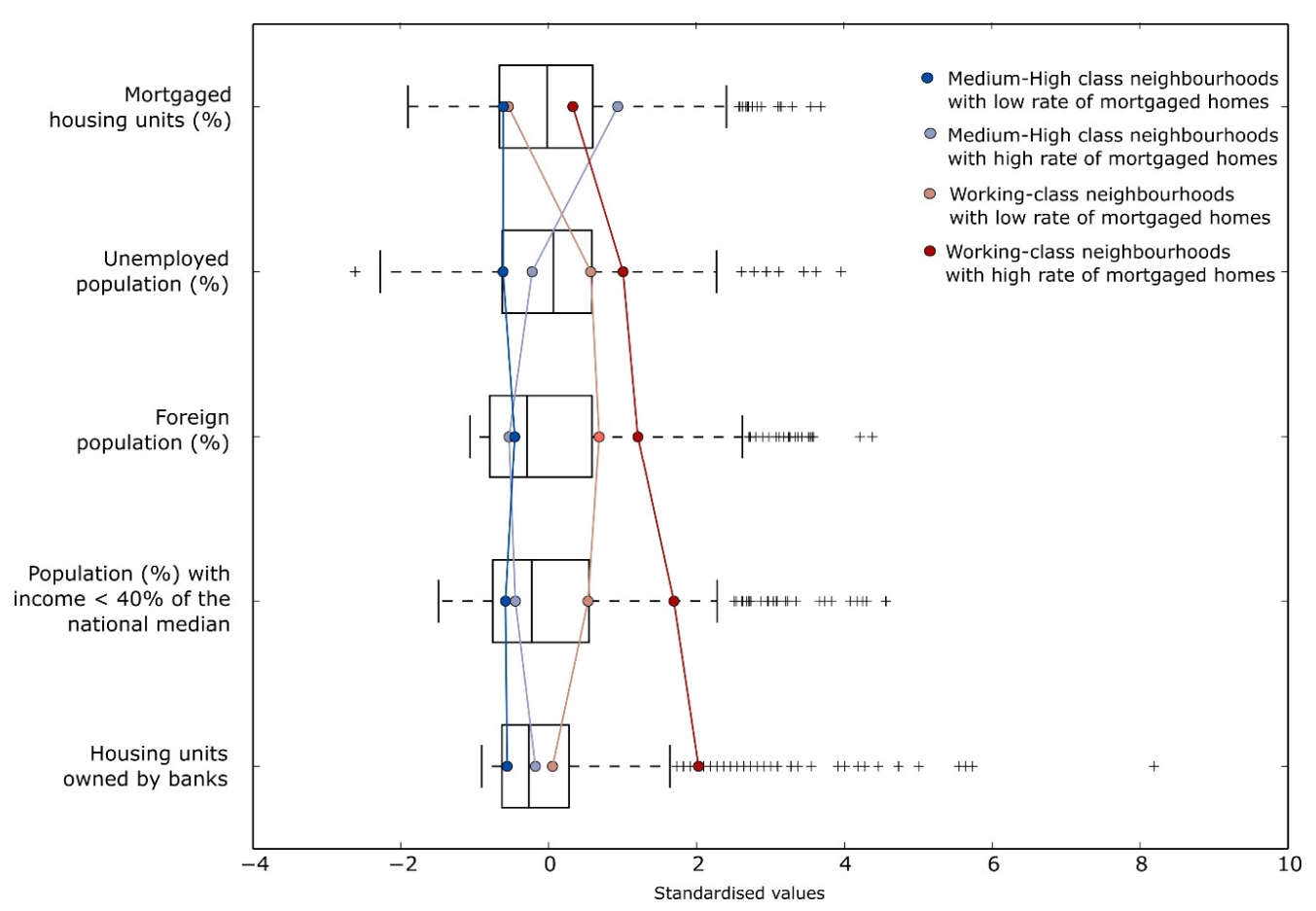

Figure 5. Standardised means for each group of neighbourhoods identified. Source: own elaboration based on data from the Catalan Housing Agency. 
From the results obtained, it was possible to clearly identify two sets of clusters. The first set contained a couple of clusters that grouped together middle and upper-class neighbourhoods. The second set of clusters contained working-class neighbourhoods. The first wealthy cluster was characterised by below-average values for all the variables studied. The second wealthy cluster was composed of neighbourhoods with high rates of exposure to housing mortgage loans. In fact, this second group clearly stood out for having the highest values for this variable, which was up to $15.3 \%$ greater than the average. Nevertheless, this high level of mortgaged homes has not involved a high ration of foreclosures in those medium-high class neighbourhoods.

The working-class neighbourhoods were characterised by the fact that they presented above average values for all of variables. As can be seen in Table 5 , their percentage of foreign population was over $25 \%$, that of unemployed people was around $20 \%$, and that of people with an income per consumption unit below $40 \%$ of the national average was over $15 \%$. However, the first vulnerable group of neighbourhoods had averages for each indicator that were 10 to 20 percentage points lower than for the second vulnerable cluster. The number of HOB in the neighbourhoods that made up the second vulnerable cluster was three times greater than the overall mean and 8.5 times greater than for the wealthiest group. In the case of working-class neighbourhoods, being an area with high presence of mortgage loans becomes a key variable that made them the areas with the highest concentration of $\mathrm{HOB}$ in all the studied cities. Although the clustering algorithm did not consider the spatial relations between neighbourhoods, the spatial distribution of these groups tended to be clustered in specific areas. Now we can confirm that these working-class neighbourhoods with high exposure to mortgage loans correspond also with the clusters of high concentration of $\mathrm{HOB}$ previously identified, as shown in Figures 4 and 6.
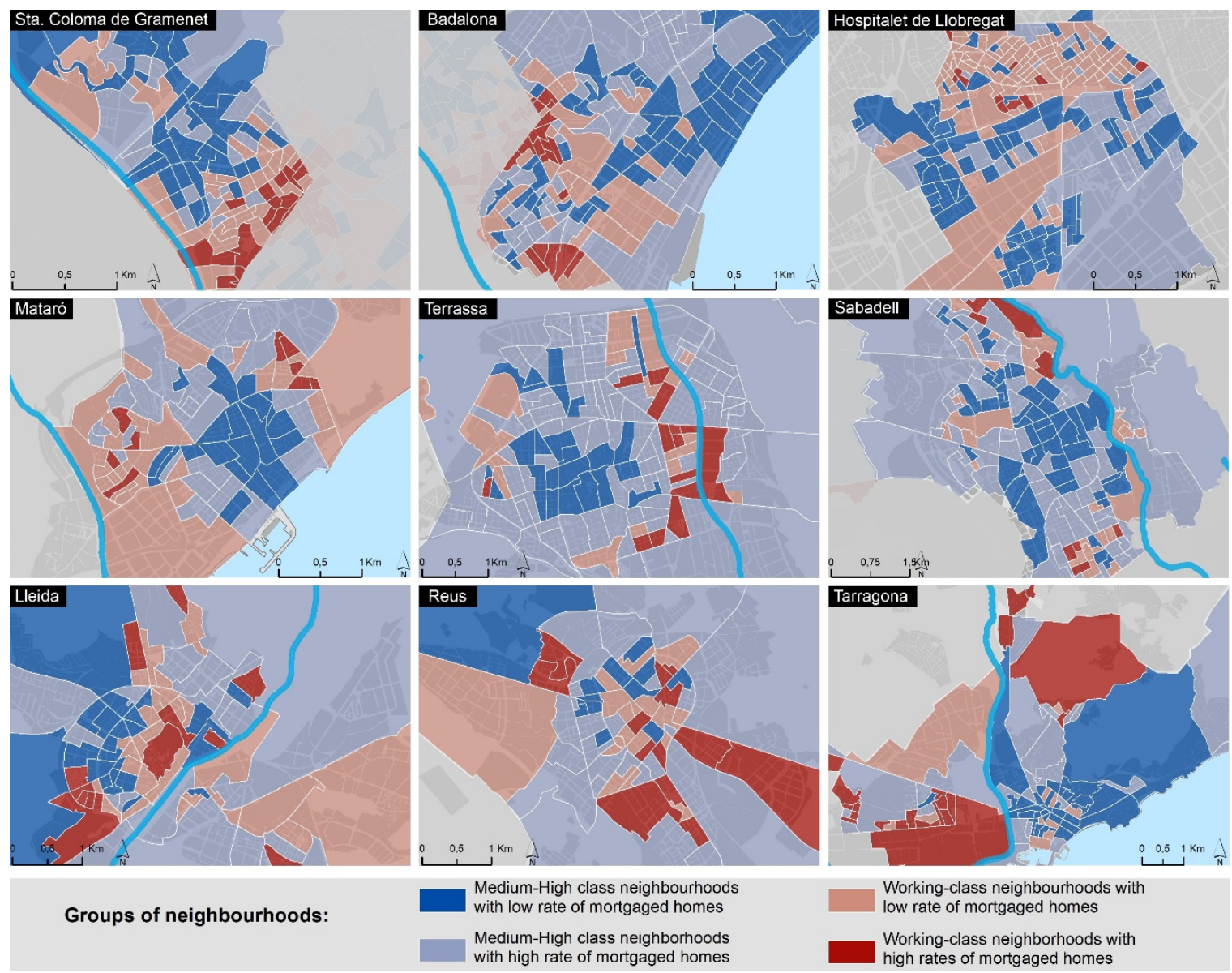

Groups of neighbourhoods:

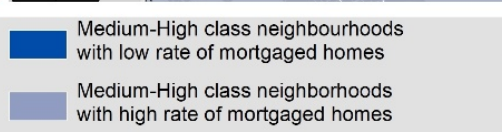
high rates of mortgaged homes

Figure 6. Spatial distribution of each of the groups of neighbourhoods identified in the nine cities studied. Source: own elaboration based on data from the Catalan Housing Agency. 


\section{Discussion and Conclusions}

\subsection{Implications of Our Findings and Main Contributions to the Field}

Based on an analysis of nine cities with over 100,000 inhabitants in Catalonia, our study presents new empirical evidence of the socio-spatial logic behind the accumulation of housing in the hands of banks via mortgage foreclosure. First of all, it provides evidence of a clear territorial pattern that was repeated in all of the cities analysed: the housing owned by banks was concentrated in certain types of neighbourhood; it was neither randomly nor homogeneously distributed within these cities. In fact, this housing tended to be clearly concentrated in the most vulnerable neighbourhoods of the Catalan cities studied. These vulnerable neighbourhoods, according to previous research, tend to have particular urban characteristics, such as housing with lower surface area [22] and a more devaluated price of housing per square metre [15]. In fact, technical studies carried out in Spanish cities based on the urban metrics, such as street width, building height or vegetation area, reported that urban typologies are strongly intertwined with socioeconomics profiles of the neighbourhoods [47]. Our findings show that the mortgage crisis, like all other capitalist crises, has tended to exacerbate existing social and spatial inequalities $[13,31,48]$.

Our work adds more evidence to previous studies carried out in both Spanish cities [22,35,36,48,49] and those in other countries throughout the world, and particularly in the USA [23,50], in which close links were also found between the socioeconomic profiles of neighbourhoods and concentrations of mortgage foreclosures. Previous studies underlined the problems that this accumulation of foreclosures and evictions can cause in these urban areas. Firstly, they cause the impoverishment of the population, but this can also set in motion a downward spiral of degradation in the neighbourhoods most affected [23-25,27-29].

Starting from this background, our study provides new evidences in the field by identifyingat neighbourhood level-the socioeconomic variables that have had the most important influence upon the spatial concentration of foreclosures. The most determinant factor appears to be the average disposable family income per census tract: the lower the income, the greater the concentration of HOB. Other import factors are the presence of foreign people and the unemployment rate. Finally, the fourth determinant variable is exposure to mortgage loan risk, although this variable behaves very differently from the others. It is evident from Figure 5 that the census sections located in middle-upper class neighbourhoods had relatively low levels of foreclosures. This occurred in both those sections with numerous mortgages in 2011 and in those that had fewer. In contrast, the group with the most foreclosures was that comprised of census sections in working-class neighbourhoods and which, on top of this, contained a high percentage of mortgaged homes in 2011. This evidence was in line with that previously observed in the city of Barcelona, based on the same data source [22], and reveals the general logic for Catalan cities as a whole.

\subsection{Limitations}

Our study presents several limitations deriving from the data source that was used. As already mentioned in the second section of the article, Spain does not have official, open-access data about evictions and mortgage foreclosures at a level of disaggregation that would make it possible to carry out an analysis with the level of detail required for this kind of research. As a result, this and other previous studies on the distribution of evictions and mortgage foreclosures have had to use alternative sources of data. Unfortunately, all of these sources have their own limitations. In our case, the main limitation was that the data used did not represent all of the housing accumulated by banks via mortgage foreclosure for a certain period. The data only related to property accumulated up to March 2016. This is all the housing units acquired via foreclosures that have not been sold until that date. Our study made it possible to characterise a process based on a source that provides a sample representing approximately $40 \%$ of the total number of evictions due to foreclosures that happened in Catalonia [12]. On the other 
hand, this source made it possible to obtain details about each of the housing units [35], its exact location [22] and the entity that had acquired it via mortgage foreclosure [12].

Another key issue derived from what was mentioned earlier is that the data used in this study provide a still image of a dynamic process. On the one hand, banks acquire housing via mortgage foreclosure, and then on the other, either derive it to the SAREB or sell it off to private individuals (a small part) or to global corporate landlords (the majority). Four years after the extraction date of the dataset (March of 2016), part of this housing now belongs to corporate landlords $[16,20]$ who bring it out onto the rental market using multiple strategies, such as retaining multiple empty housing, to obtain the maximum profit $[17,18]$. There is no freely available information about the stock accumulated by the different vulture funds, nor about its territorial distribution.

\subsection{Future Research Lines}

The first future research line should be the study of the forthcoming economical and sociodemographic changes in those working-class neighbourhoods in which a high concentration of foreclosures and home evictions has been identified. Previous studies in USA cities have reported multiple negative effects due the vicious circle of foreclosures concentration, impoverishment and neighbourhood decline [15,27-29]. This vicious circle of impoverishment, population decline and economic rundown have been studied in other Spanish contexts [51]. The potential growth of inequalities and neighbourhood degradation in the areas that are in the first line of housing instability should be explored.

The tremendous volume of housing that banks accumulated and have subsequently sold to institutional investors and global corporate landlords will mean that both of these actors will play a central role in the Spanish property market over the coming years. In fact, Blackstone is already the largest owner of housing property in the whole of Spain [19]. Various studies have analysed the role played by the global corporate landlords, investment fund, "bad banks" or other large private landlords emerged after the crash of 2007 in the management of the housing stock during the post-crisis phases in the USA [21], Australia [52], Greece [13], Ireland [20], the United Kingdom [14,20] and Spain [15,16,20]. In fact, the situation in Spain is not an isolated case, but rather a common practice around the world when it comes to "managing" housing crises. These large private landlords play a key role in the reactivation of the housing market, and assets that were accumulated via mortgage foreclosure return to the rental market to produce new profits. In this context, there is a lack of studies analysing the territorial logic of the actions of these global investment companies in cities. For this reason, a future line of research must look to analyse how this housing offer is distributed over both space and time. Within this framework, it is necessary to analyse the role that working-class neighbourhoods will play during this phase. In this study we have shown that it is in these areas where the banks have accumulated most housing via foreclosures. Our hypothesis is that despite being areas that could be subject to processes of degradation and loss of value, these neighbourhoods will be the spaces where investment funds will concentrate their activity in the rental market over the coming years.

Author Contributions: Conceptualization, Aaron Gutiérrez; methodology, Aaron Gutiérrez and Antoni Domènech; data curation, Aaron Gutiérrez and Antoni Domènech; writing_-Original draft preparation, Aaron Gutiérrez and Antoni Domènech; writing-Review and editing, Aaron Gutiérrez and Antoni Domènech; visualization, Antoni Domènech; project administration, Aaron Gutiérrez; funding acquisition, Aaron Gutiérrez and Antoni Domènech All authors have read and agreed to the published version of the manuscript.

Funding: This research was funded by the Department of Research and Universities of the Catalan Government [GRATET-2017SGR22], and the Spanish Ministry of Education and Professional Formation [Doctoral Research Grant FPU15/06947-Formación de Profesorado Universitario].

Acknowledgments: In this section you can acknowledge any support given which is not covered by the author contribution or funding sections. This may include administrative and technical support, or donations in kind (e.g., materials used for experiments).

Conflicts of Interest: The authors declare no conflict of interest. 


\section{References}

1. Burriel, E. El estallido de la burbuja inmobiliaria y sus efectos en el territorio. In Geografía de la Crisis Económica en España; Albertos Puebla, J.M., Sánchez Hernández, J.L., Eds.; Universitat de València: Valencia, Spain, 2014; pp. 101-140.

2. Romero, J.; Jimenez, F.; Villoria, M. (Un)Sustainable Territories: Causes of the Speculative Bubble in Spain (1996-2010) and its Territorial, Environmental, and Sociopolitical Consequences. Environ. Plan. C 2012, 30, 467-486. [CrossRef]

3. Vinuesa, J. El Festín de la Vivienda. Auge y Caída del Negocio Inmobiliario en España; Diaz \& Pons: Madrid, Spain, 2013.

4. Domènech, A.; Gutiérrez, A. Paisatges Després de la Batalla. Geografies de la Crisi Inmobiliària; Institut d'Estudis Catalans: Barcelona, Spain, 2018.

5. Méndez, R. La Telaraña Financiera. Una Geografía de la Financiarización y sus Crisis; IEUT-RIL Editores: Santiago de Chile, Chile, 2018.

6. Gaja, F. Tras el tsunami inmobiliario. Salir del atolladero. In Paisajes Devastados. Después del Ciclo Inmobiliario: Impactos Regionales y Urbanos de la Crisis; Traficantes de Sueños: Madrid, Spain, 2013; pp. 313-354.

7. Gutiérrez, A.; Delclòs, X. ¿Hipertrofia inmobiliaria? Análisis de las pautas territoriales del boom e implicaciones del estallido de la burbuja en Cataluña. Cuad. Geogr. 2015, 54, 283-306.

8. Méndez, R. Ciudades en Venta: Estrategias Financieras y Nuevo Ciclo Inmobiliario en España; Universitat de València: Valencia, Spain, 2020.

9. Madden, D.; Marcuse, P. In Defense of Housing: The Politics of Crisis; Verso: New York, NY, USA, 2016.

10. Vives-Miró, S.; Rullan, O.; González-Pérez, J.M. Geografies de la Despossesió D’habitatge a Través de la Crisi: Els Desnonaments Marca Palma; Icaria: Barcelona, Spain, 2018.

11. Gutiérrez, A.; Delclòs, X. Geografía de la crisis inmobiliaria en Cataluña: Una lectura a partir de los desahucios por ejecución hipotecaria. Scr. Nova 2017, 21, 7-33. [CrossRef]

12. Gutiérrez, A.; Vives-Miró, S. Acumulación de viviendas por parte de los bancos a través de los desahucios: Geografía de la desposesión de vivienda en Cataluña. Eure 2018, 44, 5-26. [CrossRef]

13. Alexandri, G.; Janoschka, M. Who Loses and Who Wins in a Housing Crisis? Lessons from Spain and Greece for a Nuanced Understanding of Dispossession. Hous. Policy Debate 2018, 28, 117-134. [CrossRef]

14. Beswick, J.; Alexandri, G.; Byrne, M.; Vives-Miró, S.; Fields, D.; Hodkinson, S.; Janoschka, M. Speculating on London's housing future. City 2016, 20, 321-341. [CrossRef]

15. Gutiérrez, A.; Domènech, A. Spanish mortgage crisis and accumulation of foreclosed housing by SAREB: A geographical approach. J. Maps 2017, 13, 130-137. [CrossRef]

16. Janoschka, M.; Alexandri, G.; Orozco Ramos, H.; Vives-Miró, S. Tracing the socio-spatial logics of transnational landlords' real estate investment: Blackstone in Madrid. Eur. Urban Reg. Stud. 2019, 27, 125-141. [CrossRef]

17. Doncel, L. Los fondos buitre reinan en España. El País, 21 May 2018. Available online: https://elpais.com/ economia/2018/04/20/actualidad/1524234866_541409.html (accessed on 1 February 2020).

18. El Confidencial. Blackstone, el mayor comprador de ladrillo español, prepara una oleada de ventas masiva. El Confidencial, 27 March 2019. Available online: https://www.elconfidencial.com/empresas/2019-03-27/ blackstone-oleada-ventas-fidere-popular_1905118/ (accessed on 1 February 2020).

19. Europa Press. Blackstone, el mayor casero de España, fusiona la gestión de 20.000 pisos en alquiler. Público, 12 January 2020. Available online: https://www.publico.es/economia/blackstone-mayor-casero-espana-fusionagestion-20000-pisos-alquiler.html (accessed on 1 February 2020).

20. Byrne, M. Generating rent and the financialization of housing: A comparative exploration of the growth of the private rental sector in Ireland, the UK and Spain. Hous. Stud. 2020, 35, 743-765. [CrossRef]

21. Fields, D. Constructing a New Asset Class: Property-led Financial Accumulation after the Crisis. Econ. Geogr. 2018, 94, 118-140. [CrossRef]

22. Gutiérrez, A.; Domènech, A. The mortgage crisis and evictions in Barcelona: Identifying the determinants of the spatial clustering of foreclosures. Eur. Plan. Stud. 2018, 26, 1939-1960. [CrossRef]

23. Leonard, T.; Murdoch, J.C. The neighborhood effects of foreclosure. J. Geogr. Syst. 2009, 11, 317. [CrossRef]

24. Libman, K.; Fields, D.; Saegert, S. Housing and Health: A Social Ecological Perspective on the US Foreclosure Crisis. Hous. Theory Soc. 2012, 29, 1-24. [CrossRef]

25. Schuetz, J.; Been, V.; Gould Ellen, I. Neighborhood effects of concentrated mortgage foreclosures. J. Hous. Econ. 2008, 17, 306-319. [CrossRef] 
26. Rugh, J.S.; Massey, D.S. Racial Segregation and the American Foreclosure Crisis. Am. Sociol. Rev. 2010, 75, 629-651. [CrossRef]

27. Immergluck, D.; Smith, G. The Impact of Single-family Mortgage Foreclosures on Neighborhood Crime. Hous. Stud. 2006, 21, 851-866. [CrossRef]

28. Immergluck, D.; Smith, G. The External Costs of Foreclosure: The Impact of Single-Family Mortgage Foreclosures on Property Values. Hous. Policy Debate 2006, 17, 57-79. [CrossRef]

29. Lin, Z.; Rosenblatt, E.; Yao, V.W. Spillover Effects of Foreclosures on Neighborhood Property Values. J. Real Estate Financ. 2009, 38, 387-407. [CrossRef]

30. García-Hernández, J.S.; Díaz-Rodríguez, M.C.; García-Herrera, L.M. Auge y crisis inmobiliaria en Canarias: Desposesión de vivienda y resurgimiento inmobiliario. Investig. Geogr. 2018, 69, 23-39. [CrossRef]

31. Méndez, R. De la Hipoteca al Desahucio: Ejecuciones Hipotecarias y Vulnerabilidad Territorial en España. Rev. Geogr. Norte Gd. 2017, 67, 9-31. [CrossRef]

32. Jiménez Barrado, V.; Sánchez Martín, J.M. Banca privada y vivienda usada en la ciudad de Madrid. Investig. Geogr. 2016, 66, 43-58. [CrossRef]

33. Parreño-Castellano, J.M.; Domínguez-Mujica, J.; Armengol-Martín, M.; Pérez García, T.; Boldú Hernández, J. Foreclosures and Evictions in Las Palmas de Gran Canaria during the Economic Crisis and Post-Crisis Period in Spain. Urban Sci. 2018, 2, 109. [CrossRef]

34. Waldron, R. The "unrevealed casualties" of the Irish mortgage crisis: Analysing the broader impacts of mortgage market financialisation. Geoforum 2016, 69, 53-66. [CrossRef]

35. Gutiérrez, A.; Arauzo-Carod, J.M. Spatial Analysis of Clustering of Foreclosures in the Poorest-Quality Housing Urban Areas: Evidence from Catalan Cities. ISPRS Int. J. Geo-Inf. 2018, 7, 23. [CrossRef]

36. García-Hernández, J.; Ginés de la Nuez, C. Geografías de la desposesión en la ciudad neoliberal: Ejecuciones hipotecarias y vulnerabilidad social en Santa Cruz de Tenerife (Canarias-España). Eure 2020, 46, 215-234.

37. González-Pérez, J.M.; Vives-Miró, S.; Rullan, O. Evictions for unpaid rent in the judicial district of Palma (Majorca, Spain): A metropolitan perspective. Cities 2020, 97, 102466. [CrossRef]

38. Anselin, L. Local indicators of spatial association-LISA. Geogr. Anal. 1995, 27, 93-115. [CrossRef]

39. Anselin, L.; Syabri, I.; Kho, Y. GeoDa: An introduction to spatial data analysis. Geogr. Anal. 2006, 38, 5-22. [CrossRef]

40. Celemín, J.P. Autocorrelación espacial e indicadores locales de asociación espacial. Importancia, estructura y aplicación. Rev. Univ. Geogr. 2009, 18, 11-31.

41. IBM. SPSS-Missing Values 25. 2017. Available online: https://www.google.com/url? $\mathrm{sa}=t \& r c t=j \& q=\& e s r c=$ s\&source=web\&cd=1\&ved=2ahUKEwig2OC2s5_pAhUjzIUKHZI2D-0QFjAAegQIARAB\&url=ftp $\% 3 A \%$ $2 \mathrm{~F} \% 2 \mathrm{Fpublic}$.dhe.ibm.com $\% 2$ Fsoftware $\% 2$ Fanalytics $\% 2$ Fspss $\% 2$ Fdocumentation $\% 2$ Fstatistics $\% 2 \mathrm{~F} 25.0 \%$ 2Fen\%2Fclient\%2FManuals\%2FIBM_SPSS_Missing_Values.pdf\&usg=AOvVaw1ks8Ok3xu6w70O64ff2S4i (accessed on 1 February 2020).

42. Chatterjee, S.; Hadi, A.S. Regression Analysis by Example, 5th ed.; Wiley: Hoboken, NJ, USA, 2012.

43. Esteban, M.; Altuzarra, A. Local Political Power and Housing Bubble in Spain. J. Reg. Res. 2016, 35, $107-127$.

44. Anselin, L. Exploring Spatial Data with GeoDa: A Workbook; Spatial Analysis Lab, University of Illinois: Urbana-Champaign, IL, USA, 2005. Available online: http://www.csiss.org/clearinghouse/GeoDa/ geodaworkbook.pdf (accessed on 1 February 2020).

45. Salas-Olmedo, M.H.; Moya-Gómez, B.; García-Palomares, J.C.; Gutiérrez, J. Tourists' digital footprint in cities: Comparing Big Data sources. Tour. Manag. 2019, 66, 13-25. [CrossRef]

46. Ministerio de Fomento. Atlas de la Vulnerabilidad Urbana; Ministerio de Fomento: Madrid, Spain, 2011. Available online: http://atlasvulnerabilidadurbana.vivienda.es/ (accessed on 1 February 2020).

47. Hermosilla, T.; Palomar-Vázquez, J.; Balaguer-Bese, Á.; Balsa-Barreiro, J.; Ruiz, L.A. Using street based metrics to characterize urban typologies. Comput. Environ. Urban Syst. 2014, 44, 68-79. [CrossRef]

48. Gutiérrez, A.; Delclòs, X. The uneven distribution of evictions as new evidence of urban inequality: A spatial analysis approach in two Catalan cities. Cities 2016, 56, 101-108. [CrossRef]

49. Vives-Miró, S.; Rullan, O.; González-Pérez, J.M. Cartografías de los desplazamientos por desposesión de vivienda. Desahucios y ejecuciones hipotecarias en Palma a través de su geohistoria. Scr. Nova 2018, 22. [CrossRef]

50. Immergluck, D. The Local Wreckage of Global Capital: The Subprime Crisis, Federal Policy and High-Foreclosure Neighborhoods in the US. Int. J. Urban Reg. Res. 2011, 35, 130-146. [CrossRef] 
51. Barreiro, J.B.; Landsperger, S. Pérdida de capital humano y desarrollo insostenible: Un círculo vicioso. Cuides 2013, 10, 55-84.

52. Pawson, H.; Martin, C. Rental property investment in disadvantaged areas: The means and motivations of Western Sydney's new landlords. Hous. Stud. 2020, 1-23. [CrossRef] 